\title{
LIGHT/BTLA polymorphisms and antibody-mediated-rejection after heart transplantation
}

\section{Grecia M. Marrón-Liñares, Lucía Núñez and Manuel Hermida-Prieto}

Antibody-mediated rejection (AMR) is one of the main problems after transplantation, partly due to the unclear aspect of the pathogenesis of AMR. Allograft rejection caused by antibodies can be mediated by different mechanisms. Classically, antibodies, produced by B-cells, induce acute rejection through the fixation and activation of the complement cascade, resulting in tissue injury [1]. Searching for new approaches to understand the pathogenesis of AMR, HVEM/LIGHT/BTLA/CD160 coestimulatory/coinhibitory signaling pathway has emerged as a potential target for immune therapy after transplantation [2].

There have been many attempts to associate solid organ allograft outcomes with specific genetic variants [3]. In fact, our group has recently found that polymorphisms in recipients and donors in genes of the complement and B-cell pathways [4-5] have been associated with AMR. However, the study of gene polymorphisms in other pathways, like HVEM/LIGHT/BTLA/CD160, could be interesting due to its role in costimulation/coinhibition of $\mathrm{T}$ and $\mathrm{B}$ cell responses, enhancing immune responses. In fact, in a recent article, published in the Vol.8 of Oncotarget, Wang et al. [6] explore the association between $H V E M / L I G H T / B T L A / C D 160$ polymorphisms and AMR after kidney transplantation. The authors used next generation sequencing (NGS) to evaluate the association between 41 single nucleotide polymorphisms (SNPs) of $H V E M / L I G H T / B T L A / C D 160$ genes in 200 renal recipients, 69 with AMR and 131 that were considered stable. Wang et al did not found any significant association between these polymorphisms and AMR in renal transplantation.

Based on the study of Wang et al, and in view of the relevant role of HVEM/LIGHT/BTLA/CD160 pathway in the immune response, we retrospectively analyzed the presence of SNPs in LIGHT/BTLA genes by NGS, due to their importance as HVEM ligands. For this purpose, 46 heart transplant recipients were analyzed, 23 with AMR and 23 matched controls without AMR. In this study, we have identified 7 SNPs in LIGHT/BTLA genes (Table 1) but, after statistical analysis, no significant association between these SNPs and AMR in heart transplantation was found.

Despite the negative results obtained by both Wang et al. and our research group in renal and cardiac transplant respectively, there is strong evidence suggesting the involvement of this pathway in immune regulation and graft rejection $[2,7]$. A possible hypothesis for this is that
Table 1: Genotype distribution of LIGHT/BTLA polymorphisms in patients with AMR and controls after heart transplantation.

\begin{tabular}{|c|c|c|c|c|c|}
\hline Gene & Genotype & Position & $\begin{array}{c}\operatorname{AMR}^{\text {AMR }}(n \\
=23)\end{array}$ & \begin{tabular}{|c|c|}
$\begin{array}{c}\text { Control } \\
=23)\end{array}$ \\
\end{tabular} & $P$-value \\
\hline \multirow{4}{*}{ LIGHT } & $\begin{array}{c}\mathrm{rs} 344560 \\
\mathrm{~T} / \mathrm{T} \\
\mathrm{T} / \mathrm{C} \\
\mathrm{C} / \mathrm{C} \\
\end{array}$ & Chr19:6665020 & $\begin{array}{c}0 \\
5 \\
18 \\
\end{array}$ & $\begin{array}{c}1 \\
6 \\
16 \\
\end{array}$ & 0.48 \\
\hline & $\begin{array}{c}\text { rs } 377184644 \\
\text { G/G } \\
\text { G/A }\end{array}$ & Chr19:6665196 & $\begin{array}{c}22 \\
1\end{array}$ & $\begin{array}{c}23 \\
0\end{array}$ & 1.00 \\
\hline & $\begin{array}{c}\text { rs } 143257425 \\
\text { G/G } \\
\text { G/A }\end{array}$ & Chr19:6665198 & $\begin{array}{c}23 \\
0\end{array}$ & $\begin{array}{c}22 \\
1\end{array}$ & 1.00 \\
\hline & $\begin{array}{c}\text { rs2291668 } \\
\text { G/G } \\
\text { G/A }\end{array}$ & Chr19:6669934 & $\begin{array}{c}15 \\
8 \\
\end{array}$ & $\begin{array}{c}17 \\
6 \\
\end{array}$ & 0.72 \\
\hline \multirow{3}{*}{ BTLA } & $\begin{array}{c}\text { rs } 9288952 \\
\text { G/G } \\
\text { G/A } \\
\text { A/A } \\
\end{array}$ & Chr3:112185025 & $\begin{array}{c}0 \\
3 \\
20 \\
\end{array}$ & $\begin{array}{c}2 \\
3 \\
18 \\
\end{array}$ & 0.48 \\
\hline & $\begin{array}{c}\text { rs76844316 } \\
\text { T/T } \\
\text { T/G } \\
\end{array}$ & Chr3:112188609 & $\begin{array}{c}23 \\
0 \\
\end{array}$ & $\begin{array}{c}22 \\
1 \\
\end{array}$ & 1.00 \\
\hline & $\begin{array}{c}\text { rs } 16859633 \\
\mathrm{~T} / \mathrm{T} \\
\mathrm{T} / \mathrm{C}\end{array}$ & Chr3:112198335 & $\begin{array}{c}23 \\
0\end{array}$ & $\begin{array}{c}22 \\
1\end{array}$ & 1.00 \\
\hline
\end{tabular}

HVEM/LIGHT/BTLA/CD160 pathway could be more related with cellular rejection (CR) than with $A M R$, due to the relevant role of this pathway in the regulation of $\mathrm{T}$ cells [2]. However, more research must be done to verify the role of $H V E M / L I G H T / B T L A / C D 160$ polymorphisms in $\mathrm{CR}$, without ruling out their possible role in AMR. It should be recalled that these genes are expressed in other cell types like B cells, NK cells, DCs, and macrophages, which are involved in AMR [1, 7]. Therefore, further research should be done in larger cohorts in order to elucidate the role of $H V E M / L I G H T / B T L A / C D 160$ polymorphisms in the progression of AMR and CR.

Manuel Hermida-Prieto: Instituto de Investigación Biomédica de la Universidad de A Coruña (INIBIC), Complexo Hospitalario Universitario de A Coruña (CHUAC)-Universidad de A Coruña, A Coruña, Spain

Correspondence to: Manuel Hermida-Prieto, email manuelhermidaprieto@gmail.com

Keywords: AMR; heart transplant; LIGHT/BTLA genes

Received: October 25, 2018

Published: November 09, 2018

\section{REFERENCES}

1. Colvin RB, et al. Nat Rev Immunol. 2005; 5:807-817. 
2. del Río ML, et al. J Leukoc Biol. 2010; 87:223-235.

3. Günesacar R, et al. Tissue Antigens. 2015; 85:104-107.

4. Marrón-Liñares GM, et al. J Heart Lung Transplant. 2018; 37:477-485.

5. Marrón-Liñares GM, et al. Circ J. 2018; 82:1351-1359.

6. Wang Z, et al. Oncotarget. 2017; 8:100079-100094. https://doi.org/10.18632/oncotarget.21941

7. Steingberg M, et al. Immunol Rev. 2011; 244:169-187.

Copyright: Marrón-Liñares et al. This is an open-access article distributed under the terms of the Creative Commons Attribution License 3.0 (CC BY 3.0), which permits unrestricted use, distribution, and reproduction in any medium, provided the original author and source are credited. 